\title{
LOGISTICAL PROCESS ANALYSIS OF A GLASS FACTORY
}

\author{
(1) Glózer Zsolt, (2) Pónusz Mónika \\ (1) Student BsC, International Business School, \\ (2) College Professor, Tomori Pál College \\ E-mail: zsoli8310@gmail.com, ponusz.monika@tpfk.hu
}

\begin{abstract}
Our paper is about the Logistical Process Analysis of the Glass Factory. The reason why this topic has been chosen is because in today's cost-sensitive world, enterprises need to participate in a strong market competition to keep operating and if those companies want to stay capable of living and make the highest profit possible, they need to overtake their competitors. The way for those firms to reduce their expenses is increasing the standards of services linked to their product and integrating, optimising them as much as possible. We had the objective of providing help to make the logistical processes of the company more efficient.

During our analyses and examinations, optimisation possibilities were mainly found in fields of stock management, storage and production, which are written about in details in our paper, including solution suggestions.

Our hypotheses proved to be true, after finishing our prior examinations and studies, using primary and secondary researches. Consequently, by adapting techniques in particular parts of logistics the found problems could be solved. However, if it comes to implementing our suggestions, it is to be considered that these are only theories at the moment. Hence, without any expertise, foresight is necessary to prevent possible difficulties and solve them.
\end{abstract}

Keywords: logistics, lean process, supply chain, MRP,

JEL classification: $L 61$

\section{Introduction}

Our study is about the analysis of the intra-logistics of a glass factory. The analysed glass factory is not a separate enterprise, but a part of an Ltd, so its single processes blend into the processes of the full company. Our observations mainly focused on the improvement of the glass factory. Our goal, among others, was that they optimize their processes and decrease their costs by analysing and reorganizing the single processes.

Logistic processes analysed in our study: Procurement, Stock management, Storage, Inverse Logistics, Distribution, and production, which is the function that creates the highest value.

I stated the following hypothesis concerning the areas that can be improved:

- stock management can be improved, especially with regards to packaging material,

- the process of warehousing could be simplified and thus, improved,

- by applying the appropriate methods production costs could be lowered. 
The methods applied at certain professional fields of logistics serve as basis for our hypothesis, by the appropriate application of which methods the problems identified in certain areas can be improved, rectified.

\section{Material and Methods}

"Value is created by the producer." (Womack-Jones, 2003) With this value creation the producer fulfils the needs of customers, and to do this, the value itself must be defined. Much of the literature, many experts studied this, considering different viewpoints, but the point of it, the creation of value, remains in the centre. James P. Womack and Daniel T. Jones conducted a global research concerning whether the managers of the companies are familiar with what constitutes as value for their customers, what are they willing to spend money on.

Another approach, which, in my opinion, defines value according to the customer from a financial viewpoint: "Value for the customer is created when the customer's feeling of usefulness due to the transaction exceeds the full ownership costs." (Chikán-Demeter, 2003).

I made a deep interview with the manager of the Glass factory. Date: 2014 April.

We are searching for the answer to the relations of certain material processes:

- Inventory management of packaging materials

- Transition analysis in the Glass factory

- Process of Warehousing

We came to the conclusion that the stocking of packaging materials can be improved to be more precise and more transparent by applying methods applied in the field of contemporary stock management. There are several transitions in the Glass factory on an annual level, the annual costs of which are high. The number of transitions could be decreased by analyses, examinations and Lean elements, and due to this, the costs would decrease too. According to our observations the process of warehousing (procurement, stock records, taking out) and its methods can be made more effective, more accurate and easier by using a logistics information system.

Thanks to the developments in the field of information studies computer software also helps our work in several cases. Our software analyses are mostly aimed at production logistics and within it, we concentrate on planning project and material needs: MRP with WinQSB software, and project management module with Gannt Project Brno software.

\section{Results and Discussion}

Procurement is connected to all logistics processes. On the other hand, because this logistics function is on the highest level of development at the company.

In this case, due to the already mentioned causes, the procurement processes of the Glass factory blend into the procurement of the parent company, Lamp production.

Strategic procurement is in place at the lamp production company, it can be concluded from the fact that procurement is at the higher levels. A combined procurement system is in use, the characteristic of which is that centralised procurement is combined with decentralised procurement and together they enhance their advantages and decrease their disadvantages. 
Companies often apply a combined procurement system, which "can have several versions; the most usual one is where the company centre and the organizational units share tasks, thus trying to combine the advantages of centralised and decentralised procurement and to eliminate their disadvantages."(Chikán-Demeter,2003)

According to the contemporary science of logistics a company can decide between three kinds of strategies concerning their suppliers: competitive (supplier is an enemy), cooperative (supplier is a partner), strategic (long term relationship, an important element of which is the exchange of information). (Demeter, 2013)

Table 1- Bill Of Material list of the Glass factory

\begin{tabular}{|l|c|}
\hline \multicolumn{2}{|c|}{ Glass BOM list } \\
\hline Name: & Integrated $(\mathrm{kg})$ \\
\hline Sand & 127,7 \\
\hline Soda & 49,5 \\
\hline Dolomite & 24,4 \\
\hline Alumina & 2,95 \\
\hline Barium-sulphate & 2,54 \\
\hline Potassium-nitrate & 2,36 \\
\hline Antimony & 0,8 \\
\hline Glass shards & 120 \\
\hline
\end{tabular}

Source: author edited table in his own

We applied the matrix based on the Bill Of Material (BOM) list of the Glass factory (see Chart 1). I found that Sand is a strategic product, in this case it is more advised to use the cooperative model. Dolomite and Soda are leverage products, the other materials of the BOM list, Alumina, Barium, Potassium and Antimony are routine products. In these cases it is more advisable to have the suppliers compete. There are no bottleneck products among the used materials.

Stock management can be closely related to procurement, since when we decided how the procurement will be done, we must also decide in what amount and when (timing) we want to procure the desired products, basic materials. It is a very useful professional area of logistics. When applied correctly, it helps us so for example our equity in stocks can be as small as possible, and we can also decrease and eliminate our losses due to stock shortage. In case of stock management it is also not advised to apply the same stocking strategy to our stocks. The $\mathrm{ABC}$ analysis is a method that can be applied well to differentiate between our stocks; it is based on the principle of Pareto and with its help we can break down our materials we wish to stock into 3 groups, and we can also apply different stocking procedures for the single groups. The principle of Vilfredo Pareto is based on his observation that " $80 \%$ of the produced goods get to $20 \%$ of society in the course of property distribution characteristic of society, so $20 \%$ of the people own $80 \%$ of the goods" (Vágány-Nagyné, 2011) This principle was adapted to countless areas of life. Also to the business life, among others, where the principles are " $80 \%$ of the income of enterprises operating in a market environment is formed due to the orders of $20 \%$ of their customers, or $80 \%$ of the profit of the company is produced by $20 \%$ of the employees, or $80 \%$ of the failed profit of companies is caused by $20 \%$ of company problems, or employees deal with tasks that define $80 \%$ of the effectiveness of the company to the extent of 20\%."(Vágány-Nagyné, 2011) The essence of the ABC analysis is that we group the stock based on their importance and we apply different stocking strategies to the single groups. Making groups can be done based on several criteria, like the costs of using the given product 
in the given period. In case of the Glass factory I took a period of one month as basis and applied the $\mathrm{ABC}$ analysis to its basic materials based on costs of use.

The analysis I conducted showed that Soda makes up for $42,51 \%$ of the costs spent on basic materials, see Table 2. This is an outstanding rate and elevates soda to be the only Category "A" material, the consequence of which is that the Glass factory is advised to put daily records in place concerning soda, and to regularly analyse lead times.

Similar procedures are advised in the case of Category "B" materials (sand, antimony and potassium), but less frequently.

In case of Category "C" materials (Barium, Alumina, dolomite) it is advised to use large batch sizes when ordering, to maintain a higher safety stock level and to conduct surveys less frequently.

In the course of my analysis I found that no restocking models are used due to which such events can manifest like the lack or surplus of packaging material the Glass factory experiences.

Table 2 - ABC analysis (Considering stocks of basic materials)

\begin{tabular}{|c|c|c|c|c|c|}
\hline BOM list & $\begin{array}{l}\text { Unit price } \\
\text { (HUF/kg) }\end{array}$ & Used amount $(\mathrm{kg}) / 1$ month & Value of Using & Decraising sequence $\%$ & Groups \\
\hline Sand & 8,7 & 172184 & 1498000,8 & Soda: 42,51 & A \\
\hline Soda & 60 & 64716 & 3882960 & Sand: 16,40 & B \\
\hline Dolomite & 7,7 & 32904 & 253360,8 & Antimony: 14,25 & B \\
\hline Alumina & 150 & 3978 & 596700 & Potassium: 10,70 & B \\
\hline Barium & 192 & 3255 & 624960 & Barium: 6,84 & $\mathrm{C}$ \\
\hline Potassium & 330 & 2961 & 977130 & Alumina: 6,63 & C \\
\hline Antimony & 2523 & 516 & 1301868 & Dolomite: 2,77 & $\mathrm{C}$ \\
\hline summa & 3271,4 & 280514 & 917673499,6 & 100 & \\
\hline
\end{tabular}

Source: author edited the table on his own

Our procured and stocked materials must be warehoused, stored. We can find several forms of warehousing in the glass factory, depending on what is stored. If finished products are stored, then the bulk storage method is used, the greatest advantage of which is that there is a very small cost involved and its use of space factor is high, however, the greatest disadvantage of it is that it is a problem for its owner to apply the FIFO principle, the presence of which would be an important factor with regards to the glass.

Furthermore, in the course of my observations I found such analogous elements in the reception-dispatch procedure of the warehouse like the requisition sheet on the picture. By eliminating these elements a much more precise, more transparent and simpler warehouse management could be implemented.

The introduction and maintenance of a linear or two-dimensional bar code system, the further advantages of which would help increase the possibility to implement the FIFO principle, due to which losses caused by it could be decreased.

The internal operation of the systems and the prediction of the critical factors' which have significant effects on the results can be difficult for a number of reasons, therefore the IT - 
system of decision support is not satisfying, despite the fact that it could be useful in many.' (Gyenge-Kozma, 2015)

\section{Positive effects of its application among others}

Production can be started from the procured and stored basic materials, which is the value creating function of the highest priority in the life of a production company, since profit is realized from the results of production.

Production must be planned, and for this we have several options considering the timescale. The production plan that deals with the largest time period is the aggregated plan. Projected data to plan it is gained from the existing orders and forecasts.

\section{Conclusion}

In the beginning of our study it was among my goals that by studying the logistics processes of the company I wish to find solutions to problems using the methods of the single fields of logistics with which the value of their products can be raised and together with it the cost per unit for one product can be decreased. Our paper mostly concentrates on creating value within the company limits of the supply chain, but in certain cases it slightly exceeds it. I endeavoured to shed light on all the participating processes.

We started our analyses with procurement as the starting point of the full value creating process. In case of the Glass factory the strategy applied to the procured base materials is greatly influenced by special requirements in the individual cases, which are demanded by the technology. In certain cases the company is depending on the individual suppliers and base material producers, and the market opportunities.

A company can tie down a high amount of equity when stocking base materials, packaging materials and half-finished and finished products, which is defined as loss in certain ways of thinking. The $\mathrm{ABC}$ analysis conducted in the case of base materials showed that soda represents a high value from the total amount dedicated to base materials, so more attention must be paid to warehousing it. Based on my observations no warehousing models are used in the case of the Glass factory, due to which events can happen like the ones experienced concerning the packaging materials. It is important to mention that the suggested restocking models can be applied to storing any material, but we must be able to identify which model can be applied to which stock.

Observing the Glass factory from the perspective of warehousing, I found that the procurement and requisition technique of the warehousing of half-finished and finished products contains such analogous elements that make it harder to perform work effectively and quickly, and provide opportunities to make mistakes. Besides, due to the analogous elements the application of the FIFO principle becomes more difficult as well. The mentioned negative factors could be greatly improved or even eliminated by introducing, maintaining the linear or two dimensional bar code system, and integrating the used ERP system.

With regards to production, based on the available data it can be observed that transitions of the Glass factory make up for $12 \%$ of the total production time, the material expenses of which greatly increase the costs of the Glass factory. In the introduction I mentioned that the elements of Lean management could be the solution to improve this rate, based on which I would firstly 
suggest SMED aimed at decreasing transition time, and the application of the "flanging machine" that can be found in the Glass factory which has a similar structure. Inadequate products and their handling are a further improvable problem, for this issue the Kaizen of the lean thinking, together with an $\mathrm{ABC}$ analysis capable of ranking mistakes could mean a longterm improvement. To decrease or avoid the so-called "stagnant stocks" and extra costs due to it a solution could be to move towards the JIT production system in certain cases. In this case fast and precise flow of information based on which production can be started is a very important criterion.

It is worth noticing that thanks to the development of information technology we can find software facilitating computer support in almost all areas of logistics, which I presented in my paper. These software products can greatly facilitate our future work, can make it more accurate, more precise, and more transparent, and provide possibilities for analyses like planning projects and material needs.

My observations concerning stocking, warehousing and production can be improved by techniques that can be applied to the individual fields of logistics. However, we must consider that my suggestions are of a theoretical nature, so special attention must be paid at their possible implementation to avoid and solve the arising difficulties.

A more tangible plan that deals with a smaller time frame is the Master Program Solution (MPS), which ranked under the aggregated plan, but at the same time it is the basis for planning material requirements. It is mandatory to adhere to it; otherwise it could result in the collapse of the system. Using a project planning software can be a great help in compliance. Such a software can be GanttProject Brno, the details of the possible application of which, reports about it I presented through an actual example. The program basically relies on the Gantt diagram, which is a graduated schedule. Its main purpose is time scheduling. It is not complicated to read the diagram. Horizontally we indicate the activities as they come after each other, and vertically we can show activities that can be performed parallel to each other.

Above I mentioned that the master program also means the basis for the material requirement planning, precision is an important condition for it as well, and to achieve said precision we can also receive software support. Such a software can be the free WinQSB, the possibility to apply it and its results can also be found. (Table 3) MRP table based on an production sample.

Based on my further studies concerning production and the available data I came to the conclusion that the time spent with transition and machine repairs make up for almost $12 \%$ of the full production. If I consider its distribution then transition is $49 \%$ of this $12 \%$ and time spent repairing machines is the remaining 51\%. Considering its costs it exceeded 66 million Forints in the year 2013. Methods used in the Lean management Kosztolányi J. - Schwahofer G. (2011) (that already proved their worth in the Japanese industry) that is greatly popular these days could be applied well to decrease these costs. From among the several techniques I suggested using the SMED in paper which serves the final purpose (through several steps) of decreasing the time of transition as drastically as it can. Furthermore, the kaizen, which aims at continuous improvement, could be successfully applied; it reaches its goal, continuous improvement, through several small development steps and the involvement of co-workers as the most experienced persons. 
Table 3. MRP final table according a production sample

\begin{tabular}{|c|c|c|c|c|c|c|c|c|}
\hline $03.06-2014$ & Overdue & Week 1 & Week 2 & Week 3 & Week 4 & Week 5 & Week 6 & Total \\
\hline Item: Egységrakomány & & $\mathbf{L T}=\mathbf{0}$ & $S S-20$ & LS - LFL & UM = Each & $\mathbf{A B C}=\mathbf{A}$ & Source = & Type - \\
\hline Gross Fequitement & $\mathbf{0}$ & $\mathbf{0}$ & $\mathbf{0}$ & 23 & 46 & $\mathbf{0}$ & 45 & 114 \\
\hline Scheduled Feceipt & $\mathbf{0}$ & $\mathbf{0}$ & $\mathbf{0}$ & $\mathbf{0}$ & $\mathbf{0}$ & $\mathbf{0}$ & $\mathbf{0}$ & $\mathbf{0}$ \\
\hline Proiected On Hand & 20 & 20 & 20 & 20 & 20 & 20 & 20 & \\
\hline Projected Net Pequirement & $\mathbf{0}$ & $\mathbf{0}$ & $\mathbf{0}$ & 23 & 46 & $\mathbf{0}$ & 45 & 114 \\
\hline Planned Order Receipt & $\mathbf{0}$ & $\mathbf{0}$ & $\mathbf{0}$ & 23 & 16 & $\mathbf{0}$ & 45 & 114 \\
\hline Planned Order Release & $\mathbf{0}$ & $\mathbf{0}$ & $\mathbf{0}$ & 23 & 46 & $\mathbf{0}$ & 45 & 114 \\
\hline Item: Folia & & LT $=\mathbf{T}$ & ss - o & LS - LFL & UM - Each & $A B C=B$ & Source - & $T_{\text {ype }}-$ \\
\hline Gross Pequirement & $\mathbf{0}$ & $\mathbf{0}$ & $\mathbf{0}$ & 506 & 1012 & $\mathbf{0}$ & 990 & 2500 \\
\hline Scheduled Receipt & $\mathbf{0}$ & $\mathbf{0}$ & $\mathbf{0}$ & $\mathbf{0}$ & $\mathbf{0}$ & $\mathbf{0}$ & $\mathbf{0}$ & $\mathbf{0}$ \\
\hline Projected On Hand & 1000 & 1000 & 1000 & 494 & $\mathbf{0}$ & $\mathbf{0}$ & $\mathbf{0}$ & \\
\hline Projected Not Requirement & $\mathbf{0}$ & $\mathbf{0}$ & $\mathbf{0}$ & $\mathbf{0}$ & 518 & $\mathbf{0}$ & 990 & 1508 \\
\hline Planned Order Receipt & $\mathbf{0}$ & $\mathbf{0}$ & $\mathbf{0}$ & $\mathbf{0}$ & 518 & $\mathbf{0}$ & 990 & 1508 \\
\hline Planned Order Release & $\mathbf{0}$ & $\mathbf{0}$ & $\mathbf{0}$ & 510 & $\mathbf{0}$ & 990 & $\mathbf{0}$ & 1500 \\
\hline Item: Elveds & & $2 T=2$ & ss $=0$ & LS - LFL & UM - E ach & $A B C=B$ & Souree - & Typo - \\
\hline Gross Pequirement & $\mathbf{0}$ & $\mathbf{0}$ & $\mathbf{0}$ & 92 & 184 & $\mathbf{0}$ & 180 & 456 \\
\hline Scheduled Aeceipt & $\mathbf{0}$ & $\mathbf{0}$ & $\mathbf{0}$ & $\mathbf{0}$ & $\mathbf{0}$ & $\mathbf{0}$ & $\mathbf{0}$ & $\mathbf{0}$ \\
\hline Proiected On Hand & 200 & 200 & 200 & 108 & $\mathbf{0}$ & $\mathbf{0}$ & $\mathbf{0}$ & \\
\hline Projected Net Bequirement & $\mathbf{0}$ & $\mathbf{0}$ & $\mathbf{0}$ & $\mathbf{0}$ & 76 & $\mathbf{0}$ & 180 & 256 \\
\hline Planned Order Receipt & $\mathbf{0}$ & $\mathbf{0}$ & $\mathbf{0}$ & $\mathbf{0}$ & 76 & $\mathbf{0}$ & 180 & 256 \\
\hline Planned Order Release & $\mathbf{0}$ & $\mathbf{0}$ & 76 & $\mathbf{0}$ & 180 & $\mathbf{0}$ & $\mathbf{0}$ & 256 \\
\hline$\overline{03-06-2014}$ & Overdue & Week 1 & Week 2 & Week 3 & Week 4 & Week 5 & Week G & Total \\
\hline Item: Hakodolop & & LT $=2$ & $s s=0$ & LS - LFL & UM = Each & $A B C=B$ & Soutce = & $T_{\text {ypo }}=$ \\
\hline Gross Pequirement & $\mathbf{0}$ & $\mathbf{0}$ & $\mathbf{0}$ & 23 & 46 & $\mathbf{0}$ & 45 & 114 \\
\hline Seheduled Receipt & $\mathbf{0}$ & $\mathbf{0}$ & $\mathbf{0}$ & $\mathbf{0}$ & $\mathbf{0}$ & $\mathbf{0}$ & $\mathbf{0}$ & $\mathbf{0}$ \\
\hline Projected On Hand & 30 & 30 & 30 & 7 & $\mathbf{0}$ & $\mathbf{0}$ & $\mathbf{0}$ & \\
\hline Projected Net Requirement & $\mathbf{0}$ & $\mathbf{0}$ & $\mathbf{0}$ & $\mathbf{0}$ & 39 & $\mathbf{0}$ & 45 & 84 \\
\hline Planned Order Receipt & $\mathbf{0}$ & $\mathbf{0}$ & $\mathbf{0}$ & $\mathbf{0}$ & 39 & $\mathbf{0}$ & 45 & 84 \\
\hline Planned Order Release & $\mathbf{0}$ & $\mathbf{0}$ & 39 & $\mathbf{0}$ & 45 & $\mathbf{0}$ & $\mathbf{0}$ & 84 \\
\hline Item: PŚntkapocs & & LT $=1$ & ss $=0$ & LS - LFL & UM = Each & $A B C=B$ & Source = & Typo = \\
\hline Gross Aequirement & $\mathbf{o}$ & $\mathbf{0}$ & $\mathbf{0}$ & 92 & 184 & $\mathbf{0}$ & 180 & 456 \\
\hline Scheduled Heceipt & $\mathbf{0}$ & $\mathbf{0}$ & $\mathbf{0}$ & $\mathbf{0}$ & $\mathbf{0}$ & $\mathbf{0}$ & $\mathbf{0}$ & $\mathbf{0}$ \\
\hline Projected On Hand & 1000 & 1000 & 1000 & 308 & 724 & 724 & 544 & \\
\hline Projected Net Requirement & $\mathbf{0}$ & $\mathbf{0}$ & $\mathbf{0}$ & $\mathbf{0}$ & $\mathbf{0}$ & $\mathbf{0}$ & $\mathbf{0}$ & $\mathbf{0}$ \\
\hline Planned Order Receipt & $\mathbf{0}$ & $\mathbf{0}$ & $\mathbf{0}$ & $\mathbf{0}$ & $\mathbf{0}$ & $\mathbf{0}$ & $\mathbf{0}$ & $\mathbf{0}$ \\
\hline Planned Order Aoleaso & $\mathbf{0}$ & $\mathbf{0}$ & $\mathbf{0}$ & $\mathbf{0}$ & $\mathbf{0}$ & $\mathbf{0}$ & $\mathbf{0}$ & $\mathbf{0}$ \\
\hline Item: Póntszalag & & LT $=1$ & $\mathrm{ss}=0$ & LS = LFL & UM = Each & $A B C=B$ & Source = & Type = \\
\hline Gross Pequirement & $\mathbf{0}$ & $\mathbf{0}$ & $\mathbf{0}$ & 529 & 1058 & $\mathbf{0}$ & 1035 & 2622 \\
\hline Seheduled Receipt & $\mathbf{0}$ & $\mathbf{0}$ & $\mathbf{0}$ & $\mathbf{0}$ & $\mathbf{0}$ & $\mathbf{0}$ & $\mathbf{0}$ & $\mathbf{0}$ \\
\hline Projected On Hand & 1000 & 1000 & 1000 & 471 & $\mathbf{0}$ & $\mathbf{0}$ & $\mathbf{0}$ & \\
\hline Projected Net Requirement & $\mathbf{0}$ & $\mathbf{0}$ & $\mathbf{0}$ & $\mathbf{0}$ & 587 & $\mathbf{0}$ & 1035 & 1622 \\
\hline Planned Order Feceipt & $\mathbf{0}$ & $\mathbf{0}$ & $\mathbf{0}$ & $\mathbf{0}$ & 587 & $\mathbf{0}$ & 1035 & 1622 \\
\hline Planned Order Release & $\mathbf{0}$ & $\mathbf{0}$ & $\mathbf{0}$ & 587 & $\mathbf{0}$ & 1035 & $\mathbf{0}$ & 1622 \\
\hline Item: Búrakóteg & & $\mathbf{L T}=\mathbf{0}$ & $S S=320$ & $\mathbf{L S}=\mathbf{L F L}$ & UM = Each & $A B C=B$ & Soutce = & $T_{\text {ype }}=$ \\
\hline Gross Requirement & $\mathbf{0}$ & $\mathbf{0}$ & $\mathbf{0}$ & 368 & 736 & $\mathbf{0}$ & 720 & 1824 \\
\hline Scheduled Receipt & $\mathbf{0}$ & $\mathbf{0}$ & $\mathbf{0}$ & $\mathbf{0}$ & $\mathbf{0}$ & $\mathbf{0}$ & $\mathbf{0}$ & $\mathbf{0}$ \\
\hline Projected On Hand & 320 & 320 & 320 & 320 & 320 & 320 & 320 & \\
\hline Projected Net Requirement & $\mathbf{0}$ & $\mathbf{0}$ & $\mathbf{0}$ & 368 & 736 & $\mathbf{0}$ & 720 & 1824 \\
\hline Planned Order Receipt & $\mathbf{0}$ & $\mathbf{0}$ & $\mathbf{0}$ & 368 & 736 & $\mathbf{0}$ & 720 & 1824 \\
\hline Planned Order Release & $\mathbf{0}$ & $\mathbf{0}$ & $\mathbf{0}$ & 368 & 736 & $\mathbf{0}$ & 720 & 1824 \\
\hline Item: Végsapka & & $L T=2$ & SS $=0$ & $\mathbf{L S}=\mathbf{L F L}$ & UM - Each & $A B C=C$ & Soutce = & Type - \\
\hline Gress Requirement & $\mathbf{0}$ & $\mathbf{0}$ & $\mathbf{0}$ & 736 & 1472 & $\mathbf{0}$ & 1440 & 3648 \\
\hline Scheduled Receipt & $\mathbf{0}$ & $\mathbf{0}$ & $\mathbf{0}$ & $\mathbf{0}$ & o & $\mathbf{0}$ & $\mathbf{0}$ & $\mathbf{0}$ \\
\hline Projected On Hand & 1500 & 1500 & 1500 & 764 & $\mathbf{0}$ & $\mathbf{0}$ & $\mathbf{0}$ & \\
\hline Projected Net Requirement & $\mathbf{0}$ & $\mathbf{0}$ & $\mathbf{0}$ & $\mathbf{0}$ & 708 & $\mathbf{0}$ & 1440 & 2148 \\
\hline Planned Order Receipt & $\mathbf{0}$ & $\mathbf{0}$ & $\mathbf{0}$ & $\mathbf{0}$ & 708 & $\mathbf{0}$ & 1440 & 2148 \\
\hline Planned Order Release & $\mathbf{0}$ & $\mathbf{0}$ & 708 & $\mathbf{0}$ & 1440 & $\mathbf{0}$ & $\mathbf{0}$ & 2148 \\
\hline
\end{tabular}

Source: author edited the table on his own 
Regardless of my suggestions I had to notice in the course of my analyses that the glass production technology does not make it possible for the company to use a purely pull-based system, the consequence of which is that it is not possible to create a glass factory actually built on Toyota philosophy.

Based on my observations it can be said in the Glass factory:

- Stocking can be improved with the techniques of stock management,

- Warehousing can be made simpler and can be improved by using a Logistics Information System and

- Extra costs that arise due to transitions and machine repairs in the field of Production can be decreased by using the methods applied in Lean management.

In the course of my observations I found that the perspectives of logistics are not applied in the glass factory, and because of this reason my analyses performed in the paper provide an appropriate basis for further studies to be conducted in the individual fields.

\section{References:}

1. Benkő J. (2009): Logisztika I. LOKA, Gödöllő

2. Chikán A. - Demeter K. (2003): Az értékteremtő folyamatok menedzsmentje. 3. kiad. Budapest, AULA

3. Demeter K. (2013): Az értékteremtés folymatai. Budapesti Corvinus Egyetem, Vállalat gazdaságtan Intézet

4. Földesi P. (2006): Logisztika I.-II. Győr, ISBN 9634317960

5. Gyenge B. - Kozma T.(2015): Szimulációs modellezés a raktárlogisztikában. In: Karmazin György (föszerk): LOGISZTIKA Trendek és legjobb gyakorlatok, I. évfolyam, 1. szám, Szolnok, 2015. április, 22-24. oldal, ISSN: 2416-0555

6. Kosztolányi J. - Schwahofer G. (2011): Lean szótár 2. 2. kiad. Budapest Kaizen Pro

7. Réger B. (2010): A logisztikai technológiai folyamatok tervezése - II. Rakodási logisztikai technológia. Budapest, ÁVF

8. Vágány J. - Nagyné Pércsi K. (2011): Minőségmenedzsment. Budapest, ÁVF

9. Womack, J. P. - Jones T. J. (2009): Lean szemlélet (Lean thinking), Budapest, HVG kiadó 